\title{
Effect of wood flour as carbon source on cellulases and xylanases production by white-rot-fungi native from Misiones
}

\author{
M. D. Rodríguez ${ }^{1}$, M. L. Barchuk ${ }^{1}$, M. I. Fonseca ${ }^{1}$, P. D. Zapata ${ }^{1}$, L. L. Villalba ${ }^{1}$ \\ ${ }^{1}$ Laboratorio de Biotecnología Molecular, Instituto de Biotecnología de Misiones (InBioMis), Facultad de Ciencias \\ Exactas, Químicas y Naturales, Universidad Nacional de Misiones. Ruta Nacional 12, km 7.5. Posadas, \\ Misiones, Argentina.
}

biotecmol2010@gmail.com

\begin{abstract}
There is a need to explore lignocellulosic materials to select an adequate substrate for lignocellulolytic enzyme production. Utilization of some residues provides an opportunity to produce high yields of lignocellulolytic enzymes in a simple medium. The aim of the present work was to study the effect of wood flour as a carbon source on the cellulolytic and xylanolytic secretion of white-rot fungi native from Misiones. Fungi were incubated with $5 \mathrm{~g}$ Pinus sp. wood flour/L and $5 \mathrm{~g}$ Eucalyptus sp. wood flour/L as carbon sources in a reciprocal shaker at $80 \mathrm{rpm}$ and $29^{\circ} \mathrm{C}$ for 15 days. Total cellulase, endo-1,4- $\beta$-glucanase, $\beta$-glucosidase, cellobiohydrolase and endo-1,4- $\beta$-xylanase activities were determined in culture supernatants. Tested fungi showed high endo-1,4- $\beta$-xylanase activity between 6 and 12 days. Total cellulase showed the highest activity between 12-15 culture days. The test did not show differences among Pycnoporus sanguineus LBM 014, $P$. sanguineus BAFC 2126, Irpex lacteus BAFC 1171, Irpex sp. LBM 032, Irpex sp. LBM 034 and Lenzites elegans BAFC 2127 , showing the highest activity for this group regard the others strains. I. lacteus BAFC 1171 was the strain with major endo-1,4- $\beta$-glucanase activity at day 9 (847 U/L). In the case of $\beta$-glucosidase and cellobiohydrolase, $P$. sanguineus BAFC 2126 was the strain with the highest activity between $12-15$ culture days (18 U/L), and between $9-15$ culture days (39 U/L), respectively. Wood flour proved to be a suitable carbon source to produce hydrolytic enzymes. I. lacteus BAFC 1171 and $P$. sanguineus BAFC 2126 have potential for cellulase production whereas $P$. sanguineus LBM 008 is a good endo-1,4- $\beta$-xylanase producer.
\end{abstract}

\section{Indexing terms/Keywords}

Cellulase, endo-1,4- $\beta$-xylanase, white-rot fungi, wood flour.

\section{Academic Discipline And Sub-Disciplines}

Biotechnology.

\section{SUBJECT CLASSIFICATION}

Microbiology.

\section{TYPE (METHOD/APPROACH)}

Quasi-Experimental.

\section{Council for Innovative Research}

\author{
Peer Review Research Publishing System
}

\author{
Journal: JOURNAL OF ADVANCES IN BIOTECHNOLOGY \\ Vol .5, No. 1 \\ www.cirjbt.org , jbteditor@gmail.com
}




\section{INTRODUCTION}

The availability of fossil fuel resources and the increasing energy demand are the main driving forces in the search for alternative energy sources. The large-scale replacement of petroleum fuels by biofuels, such as ethanol from lignocellulosic materials appears to be a powerful approach to meet the growing energy demands [1]. The lignocellulosic material from softwood source contains about $44 \%$ cellulose, $21 \%$ hemicellulose and $28 \%$ lignin [2], while hardwood has $40 \%$ cellulose, $17 \%$ hemicellulose and $21 \%$ lignin [3]. To breakdown polymeric sugars in an environmental friendly process, it is necessary to decrease the cost of cellulases and hemicellulases production, to increase volumetric productivity, to use cheaper substrates and to produce enzymes with high stability [4].

There are many microorganisms able to hydrolyze cellulose and hemicellulose. The description and analysis of new enzymes with distinctive biochemical properties from the rich and vast biodiversity of our region can reveal peculiar and worthy capacities. White-rot fungi have the ability to degrade most of wood components due to their capacity to synthesize hydrolytic extracellular enzymes. Potential applications of lignocellulolytic enzymes in industrial and environmental biotechnology require huge amounts of these enzymes at the lowest cost possible [5]. The enzyme cost is one of the factors determining the economics of a biocatalytic process and it can be reduced with optimum conditions for their production [6-7]. Hence, finding new microbial strains able to produce cellulases and xylanases and increasing the hydrolytic activity of fungal culture extracts is a way to lower the cost of enzymes used in hydrolysis of polymeric sugars to fermentable sugars.

Submerged liquid cultures (SLC) are widely used for enzyme production [8-10]. Synthetic media, such as carboxymethyl cellulose, xylan, cellulose powder and glucose, are usually used for cellulolytic and xylanolytic enzyme production [11-13]. However the cost of raw materials constitutes a large part of the total production cost [14-15]. Hence, there is a need to explore lignocellulosic materials to select an adequate substrate for enzyme synthesis to fully express and correctly evaluate the lignocellulolytic potential of fungi. Utilization of some residues provides an opportunity to produce high yields of lignocellulolytic enzymes in a simple medium [5].

The aim of the present work was to study the effect of wood flour as a carbon source on the cellulolytic and xylanolytic secretion of white-rot fungi native from Misiones.

\section{MATERIALS AND METHODS}

\subsection{Microorganisms}

Coriolus versicolor f. antarcticus BAFC 266, Pycnoporus sanguineus BAFC 2126, Lenzites elegans BAFC 2127, Trametes villosa BAFC 2755 and Irpex lacteus BAFC 1171 were provided by the Mycological Culture Collection of the Department of Biological Sciences, Faculty of Exact and Natural Sciences, University of Buenos Aires, Argentina. Ganoderma sp. LBM 001, Trametes villosa LBM 002, Trametes sp. LBM 003, Trametes sp. LBM 004, Pycnoporus sanguineus LBM 008, Trametes sp. LBM 009, Trametes villosa LBM 010, Lentinus sp. LBM 011, Pycnoporus sanguineus LBM 014 Schyzophyllum sp. LBM 015, Trametes elegans LBM 017, Trametes villosa LBM 018, Trametes sp. LBM 029, Trametes sp. LBM 030, Trametes sp. LBM 031, Irpex sp. LBM 032, Trametes sp. LBM 033, Irpex sp. LBM 034 and Pleurotus sajorcaju LBM 105 were provided by the Laboratory of Molecular Biotechnology Culture Collection, Institute of Biotechnology of Misiones, Argentina.

\subsection{Raw material}

Sawdust from Pinus sp. and Eucalyptus sp. were collected from Valerio Oliva S.A. saw mill. Both materials were air-dried until $10 \%$ moisture, ground in a hammer mill and sieved. The Pinus sp. wood flour (PWF) and Eucalyptus sp. wood flour (EWF) was classified by screening on a 40 mesh sieve. Total solid, extractives and lignin content were determined according to standard protocol NREL/TP-510-42621, NREL/TP-510-42619, NREL/TP-510-42618, respectively [16-18]. Total carbohydrates were measured according to López-Miranda et al. [19].

\subsection{Culture conditions}

Fungi were first cultured on malt extract agar for 5 days at $29^{\circ} \mathrm{C}$. To prepare the pre-inoculum, two $78 \mathrm{~mm}^{2}$ agar-plugs from each fungus were cut and transferred to $100 \mathrm{~mL}$ Erlenmeyer flasks containing $20 \mathrm{~mL}$ of modified Mandels media [12] and $5 \mathrm{~g}$ glucose/L, incubated at $29^{\circ} \mathrm{C}$ in static conditions for 13 days. The pre-inoculum was washed with sterile distilled water and transferred to $250 \mathrm{~mL}$ Erlenmeyer flasks containing $60 \mathrm{~mL}$ of modified Mandels medium at pH $5 \mathrm{with} 5 \mathrm{~g} \mathrm{PWF/L}$ and $5 \mathrm{~g} \mathrm{EWF/L}$ as carbon sources. The flasks were placed in a reciprocal shaker at $80 \mathrm{rpm}$ and $29^{\circ} \mathrm{C}$ for 15 days. At regular intervals of $72 \mathrm{~h}$, samples of culture supernatants were collected and stored at $-20^{\circ} \mathrm{C}$. Each experiment was performed in duplicate.

\subsection{Enzyme assays}

The total cellulase (FPA) and endo-1,4- $\beta$-glucanase (EGs - EC 3.2.1.6) activities were determined according to International Union of Pure and Applied Chemistry [20]. The $\beta$-glucosidase (BGLs - EC 3.2.1.21) activity was determined by assaying the release of $p$-nitrophenol [21]. The cellobiohydrolase (CBHs - EC 3.2.1.91) activity was determined according to Wood and Bhat [22]. Endo-1,4- $\beta$-xylanase (EXs - EC 3.2.1.8) activity was measured in $0.1 \mathrm{~mL}$ of culture supernatants in $50 \mathrm{mM}$ acetate buffer $\left(\mathrm{pH} \mathrm{4.8)}\right.$ for $60 \mathrm{~min}$ at $50^{\circ} \mathrm{C}$ using $0.1 \mathrm{~mL}$ of $1 \%(\mathrm{w} / \mathrm{v})$ xylan from beechwood (SIGMA) as substrate. The released reducing sugars were assayed using DNS method [23]. One unit of FPA, EGs, CBHs 
and EXs activity was defined as the amount of enzyme required to liberate $1 \mu \mathrm{mol} / \mathrm{mL}$ min of glucose from the particular substrate under the assay conditions. One unit of BGLs was defined as the amount of enzyme required to liberate 1 $\mu \mathrm{mol} / \mathrm{mL}$ min of $\mathrm{p}$-nitrophenol under the assay conditions.

\subsection{Statistical analysis}

Two-way ANOVA with multiple range test was performed using the Statgraphic Centurion program (StatPoint, Inc.).

\section{RESULTS}

\subsection{Compositional analysis}

The chemical composition of both PWF and EWF was determined and the results are tabulated in Table 1.

Table 1. Compositional analysis of PWF and EWF.

\begin{tabular}{|ccc|}
\hline Constituent & PWF [\%] & EWF [\%] \\
\hline Carbohydrates & $65,17 \pm 0,74$ & $69,9 \pm 2,11$ \\
Lignin & $24,45 \pm 1,31$ & $12,01 \pm 0,93$ \\
Extractives & $1,82 \pm 0,29$ & $1,27 \pm 0,13$ \\
\hline
\end{tabular}

\subsection{Cellulolytic and xylanolytic activities}

The FPA activities are shown in Table 2. These activities were used for ANOVA.

Table 2. Total cellulase activity for each strain grown in wood flour as carbon source.

\begin{tabular}{|c|c|c|c|c|c|c|}
\hline \multirow{3}{*}{ Strain } & \multicolumn{6}{|c|}{ Cellulase activity [FPA/L] } \\
\hline & \multirow[b]{2}{*}{0} & \multirow[b]{2}{*}{3} & \multicolumn{2}{|c|}{ Culture days } & \multirow[b]{2}{*}{12} & \multirow[b]{2}{*}{15} \\
\hline & & & 6 & 9 & & \\
\hline Coriolus versicolor f. antarcticus BAFC 266 & $21 \pm 2$ & $25 \pm 1$ & $19 \pm 6$ & $25 \pm 5$ & $29 \pm 6$ & $29 \pm 3$ \\
\hline Ganoderma sp. LBM 001 & $24 \pm 1$ & $18 \pm 1$ & $26 \pm 14$ & $50 \pm 16$ & $58 \pm 19$ & $62 \pm 17$ \\
\hline Irpex lacteus BAFC 1171 & $25 \pm 1$ & $45 \pm 6$ & $71 \pm 23$ & $65 \pm 10$ & $47 \pm 7$ & $73 \pm 1$ \\
\hline Irpex sp. LBM 032 & $25 \pm 3$ & $25 \pm 2$ & $72 \pm 33$ & $82 \pm 25$ & $50 \pm 15$ & $116 \pm 21$ \\
\hline Irpex sp. LBM 034 & $27 \pm 2$ & $55 \pm 5$ & $47 \pm 3$ & $65 \pm 5$ & $102 \pm 1$ & $83 \pm 26$ \\
\hline Lentinus sp. LBM 011 & $29 \pm 4$ & $26 \pm 1$ & $24 \pm 1$ & $26 \pm 3$ & $23 \pm 4$ & $38 \pm 18$ \\
\hline Lenzites elegans BAFC 2127 & $25 \pm 1$ & $32 \pm 16$ & $40 \pm 16$ & $84 \pm 45$ & $111 \pm 47$ & $116 \pm 33$ \\
\hline Pleurotus sajor-caju LBM 105 & $27 \pm 4$ & $25 \pm 1$ & $26 \pm 13$ & $38 \pm 14$ & $43 \pm 16$ & $48 \pm 18$ \\
\hline Pycnoporus sanguineus BAFC 2126 & $22 \pm 1$ & $29 \pm 6$ & $78 \pm 18$ & $71 \pm 22$ & $73 \pm 2$ & $40 \pm 1$ \\
\hline Pycnoporus sanguineus LBM 008 & $29 \pm 6$ & $30 \pm 2$ & $21 \pm 1$ & $38 \pm 9$ & $39 \pm 11$ & $47 \pm 16$ \\
\hline Pycnoporus sanguineus LBM 014 & $26 \pm 4$ & $73 \pm 7$ & $43 \pm 7$ & $42 \pm 2$ & $57 \pm 2$ & $56 \pm 15$ \\
\hline Schyzophyllum sp. LBM 015 & $24 \pm 2$ & $27 \pm 3$ & $33 \pm 11$ & $34 \pm 11$ & $32 \pm 10$ & $41 \pm 13$ \\
\hline Trametes elegans LBM 017 & $27 \pm 5$ & $23 \pm 2$ & $20 \pm 5$ & $30 \pm 5$ & $29 \pm 5$ & $35 \pm 1$ \\
\hline Trametes sp. LBM 003 & $21 \pm 1$ & $28 \pm 8$ & $20 \pm 9$ & $33 \pm 11$ & $36 \pm 12$ & $39 \pm 14$ \\
\hline Trametes sp. LBM 004 & $28 \pm 1$ & $24 \pm 1$ & $44 \pm 17$ & $27 \pm 1$ & $25 \pm 1$ & $27 \pm 2$ \\
\hline Trametes sp. LBM 009 & $25 \pm 3$ & $26 \pm 3$ & $19 \pm 4$ & $15 \pm 4$ & $25 \pm 11$ & $27 \pm 1$ \\
\hline Trametes sp.LBM 029 & $24 \pm 2$ & $27 \pm 1$ & $23 \pm 1$ & $21 \pm 3$ & $26 \pm 1$ & $25 \pm 1$ \\
\hline Trametes sp. LBM 030 & $18 \pm 1$ & $22 \pm 1$ & $24 \pm 2$ & $25 \pm 1$ & $29 \pm 1$ & $25 \pm 3$ \\
\hline Trametes sp. LBM 031 & $26 \pm 1$ & $23 \pm 1$ & $18 \pm 1$ & $22 \pm 1$ & $25 \pm 5$ & $29 \pm 2$ \\
\hline Trametes sp. LBM 033 & $25 \pm 3$ & $21 \pm 1$ & $26 \pm 1$ & $23 \pm 1$ & $28 \pm 5$ & $25 \pm 1$ \\
\hline Trametes villosa LBM 002 & $32 \pm 4$ & $24 \pm 1$ & $14 \pm 1$ & $15 \pm 1$ & $26 \pm 1$ & $24 \pm 1$ \\
\hline Trametes villosa LBM 010 & $22 \pm 5$ & $24 \pm 1$ & $14 \pm 1$ & $22 \pm 14$ & $41 \pm 7$ & $43 \pm 1$ \\
\hline Trametes villosa LBM 018 & $22 \pm 1$ & $23 \pm 1$ & $20 \pm 6$ & $24 \pm 4$ & $24 \pm 4$ & $24 \pm 3$ \\
\hline Trametes villosa BAFC 2755 & $27 \pm 3$ & $25 \pm 1$ & $14 \pm 1$ & $13 \pm 1$ & $22 \pm 2$ & $21 \pm 2$ \\
\hline
\end{tabular}


The EXs activities are shown in Table 3. Most of the tested fungi showed high EXs activity between 6 and 12 days without significant differences. Twelve of the twenty four strains exhibited the highest EXs activity between 6 and 9 days of incubation. Trametes sp. LBM 004 produced $42 \mathrm{U} / \mathrm{L}$ on the $6^{\text {th }}$ culture day, $P$. sanguineous LBM $00841 \mathrm{U} / \mathrm{L}$ on the day 9 and T. elegans LBM $01746 \mathrm{U} / \mathrm{L}$ on the $12^{\text {th }}$ culture day. These activities were used for ANOVA.

Table 3. Endo-1,4- $\beta$-xylanase activity for each strain grown in wood flour as carbon source.

\begin{tabular}{|c|c|c|c|c|c|c|}
\hline \multirow{3}{*}{ Strain } & \multicolumn{6}{|c|}{ Endo-1,4- $\beta$-xylanase activity [U/L] } \\
\hline & \multicolumn{6}{|c|}{ Culture days } \\
\hline & 0 & 3 & 6 & 9 & 12 & 15 \\
\hline Coriolus versicolor f. antarcticus BAFC 266 & $0 \pm 0$ & $2 \pm 0$ & $6 \pm 6$ & $27 \pm 9$ & $5 \pm 4$ & $2 \pm 0$ \\
\hline Ganoderma sp. LBM 001 & $3 \pm 1$ & $4 \pm 1$ & $8 \pm 3$ & $6 \pm 3$ & $3 \pm 1$ & $2 \pm 1$ \\
\hline Irpex lacteus BAFC 1171 & $10 \pm 0$ & $22 \pm 1$ & $21 \pm 1$ & $21 \pm 1$ & $27 \pm 3$ & $32 \pm 5$ \\
\hline Irpex sp. LBM 032 & $0 \pm 0$ & $3 \pm 0$ & $5 \pm 0$ & $7 \pm 1$ & $5 \pm 0$ & $3 \pm 2$ \\
\hline Irpex sp. LBM 034 & $3 \pm 0$ & $15 \pm 1$ & $23 \pm 1$ & $14 \pm 1$ & $22 \pm 1$ & $6 \pm 1$ \\
\hline Lentinus sp. LBM 011 & $4 \pm 1$ & $8 \pm 2$ & $17 \pm 2$ & $20 \pm 3$ & $33 \pm 4$ & $11 \pm 1$ \\
\hline Lenzites elegans BAFC 2127 & $3 \pm 1$ & $7 \pm 2$ & $10 \pm 6$ & $28 \pm 6$ & $21 \pm 1$ & $13 \pm 1$ \\
\hline Pleurotus sajor-caju LBM 105 & $3 \pm 3$ & $1 \pm 1$ & $7 \pm 4$ & $12 \pm 1$ & $13 \pm 0$ & $12 \pm 1$ \\
\hline Pycnoporus sanguineus BAFC 2126 & $5 \pm 5$ & $32 \pm 4$ & $35 \pm 2$ & $14 \pm 1$ & $15 \pm 4$ & $9 \pm 2$ \\
\hline Pycnoporus sanguineus LBM 008 & $0 \pm 0$ & $34 \pm 0$ & $37 \pm 0$ & $41 \pm 1$ & $33 \pm 7$ & $37 \pm 1$ \\
\hline Pycnoporus sanguineus LBM 014 & $4 \pm 1$ & $5 \pm 0$ & $5 \pm 2$ & $12 \pm 2$ & $6 \pm 1$ & $8 \pm 4$ \\
\hline Schyzophyllum sp. LBM 015 & $3 \pm 1$ & $16 \pm 4$ & $6 \pm 4$ & $8 \pm 1$ & $6 \pm 1$ & $3 \pm 1$ \\
\hline Trametes elegans LBM 017 & $4 \pm 1$ & $15 \pm 3$ & $25 \pm 5$ & $28 \pm 6$ & $46 \pm 4$ & $10 \pm 2$ \\
\hline Trametes sp. LBM 003 & $2 \pm 2$ & $15 \pm 3$ & $26 \pm 3$ & $13 \pm 2$ & $19 \pm 9$ & $13 \pm 2$ \\
\hline Trametes sp. LBM 004 & $3 \pm 3$ & $23 \pm 1$ & $42 \pm 8$ & $24 \pm 12$ & $31 \pm 8$ & $23 \pm 3$ \\
\hline Trametes sp. LBM 009 & $4 \pm 4$ & $22 \pm 6$ & $16 \pm 2$ & $14 \pm 2$ & $18 \pm 1$ & $24 \pm 1$ \\
\hline Trametes sp.LBM 029 & $3 \pm 1$ & $4 \pm 0$ & $13 \pm 5$ & $21 \pm 6$ & $7 \pm 2$ & $5 \pm 1$ \\
\hline Trametes sp. LBM 030 & $4 \pm 0$ & $15 \pm 3$ & $5 \pm 2$ & $4 \pm 0$ & $6 \pm 6$ & $0 \pm 0$ \\
\hline Trametes sp. LBM 031 & $4 \pm 1$ & $21 \pm 1$ & $13 \pm 1$ & $8 \pm 1$ & $5 \pm 2$ & $4 \pm 1$ \\
\hline Trametes sp. LBM 033 & $3 \pm 0$ & $0 \pm 0$ & $4 \pm 0$ & $19 \pm 0$ & $20 \pm 1$ & $21 \pm 4$ \\
\hline Trametes villosa LBM 002 & $3 \pm 1$ & $28 \pm 2$ & $37 \pm 2$ & $34 \pm 1$ & $43 \pm 5$ & $6 \pm 6$ \\
\hline Trametes villosa LBM 010 & $3 \pm 3$ & $20 \pm 2$ & $15 \pm 3$ & $15 \pm 1$ & $14 \pm 2$ & $2 \pm 1$ \\
\hline Trametes villosa LBM 018 & $4 \pm 1$ & $10 \pm 1$ & $19 \pm 6$ & $28 \pm 4$ & $31 \pm 4$ & $11 \pm 3$ \\
\hline Trametes villosa BAFC 2755 & $1 \pm 1$ & $9 \pm 3$ & $22 \pm 9$ & $16 \pm 1$ & $17 \pm 2$ & $12 \pm 3$ \\
\hline
\end{tabular}

Results from ANOVA are given in Table 4. Main effects (Time and Strain) and interaction (Time $x$ Strain) were statistically significant for total cellulases and EXs $(p<0.05)$. Multiple range tests were performed to determine statistical differences between each level of main effects.

Table 4. A) ANOVA for FPA. B) ANOVA for EXs activity.

\begin{tabular}{|c|c|c|c|c|c|c|}
\hline & Source & Sum of squares & Gf & Mean square & Ratio-F & P-value \\
\hline \multirow[t]{7}{*}{$\mathbf{A}$} & Main effects & & & & & \\
\hline & A:Time & 14.7277 & 5 & 2.94555 & 18.24 & 0.0000 \\
\hline & B:Strain & 59.9663 & 23 & 2.60723 & 16.15 & 0.0000 \\
\hline & \multicolumn{6}{|l|}{ Interaction } \\
\hline & $A B$ & 44.2764 & 115 & 0.385012 & 2.38 & 0.0000 \\
\hline & Residues & 23.2525 & 144 & 0.161476 & & \\
\hline & Total (corrected) & 142.223 & 287 & & & \\
\hline
\end{tabular}




\begin{tabular}{|llllll|}
\hline B $\quad$ Main effects & & & & & \\
A:Time & 8355.98 & 5 & 1671.2 & 84.57 & 0.0000 \\
B:Strain & 13993.7 & 23 & 608.42 & 30.79 & 0.0000 \\
Interaction & & & & & \\
AB & 12422.4 & 115 & 108.021 & 5.47 & 0.0000 \\
$\quad$ Residues & 2845.5 & 144 & 19.7604 & & \\
Total (corrected) & 37617.6 & 287 & & & \\
\hline
\end{tabular}

For FPA, the multiple range tests run for all fungi did not show significant differences between 12 and 15 days, showing the highest activity in this period. Concerning the strain effect, the test did not show significant differences among $P$. sanguineus LBM 014, $P$. sanguineus BAFC 2126, I. lacteus BAFC 1171, Irpex sp. LBM 032, Irpex sp. LBM 034 and $L$. elegans BAFC 2127, showing the highest activity for this group regard the others strains. Regarding cellulose activity results, Irpex sp. LBM 032 and $L$. elegans BAFC 2127 exhibited the highest values of activity on the $15^{\text {th }}$ culture day (116 $\mathrm{U} / \mathrm{L})$, $P$. sanguineus LBM 014 secreted $73 \mathrm{U} / \mathrm{L}$ on the $3^{\text {rd }}$ culture day, $P$. sanguineus BAFC $212678 \mathrm{U} / \mathrm{L}$ on the $6^{\text {th }} \mathrm{culture}$ day, and Irpex sp. LBM $034102 \mathrm{U} / \mathrm{L}$ on the $12^{\text {th }}$ culture day.

The strains exhibiting the highest FPA were tested for EGs, BGLs and CBHs (Figure 1). ANOVA test was performed for EGs, BGLs and CBHs. The analysis showed significant differences at $95 \%$ for each factor (Strain and Time) and interaction (Strain $x$ Time). The multiple range tests showed that $I$. lacteus BAFC 1171 was the strain with highest EGs activity at $9^{\text {th }}$ day $(847 \mathrm{U} / \mathrm{L})$, with statistical differences among the other strains. Regarding BGLs and CBHs, $P$. sanguineus BAFC 2126 was the strain with the highest significant activity between 12-15 culture days (18 U/L), and between $9-15$ culture days (39 U/L), respectively.
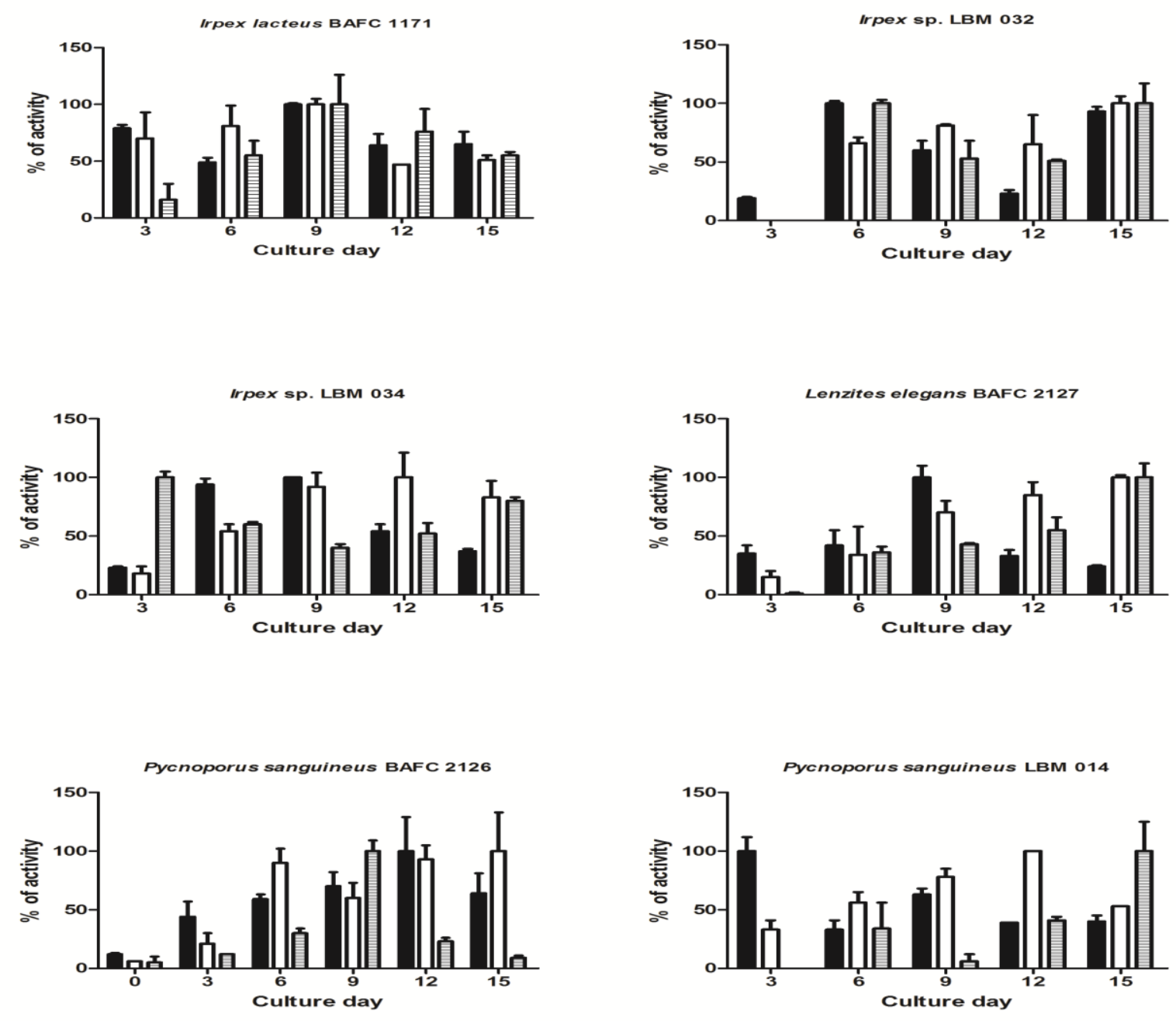

Figure 1. Activity percentage of EGs ( $₫$ ), BGLs ( $\square$ y CBHs (目 of each strain a function of culture day. $100 \%$ activity is the maximum activity value for each enzyme. 


\section{DISCUSSION}

The wood material has about $40-50 \%$ cellulose, $25-35 \%$ hemicellulose and $20-35 \%$ lignin [24]. These results agree with Table 1 and many authors [3, 25-26]. Differences in some of the components may be seasonal or due to species differences.

For an industrial application it is important to obtain high enzyme activity in the shortest possible period of time. $P$. sanguineus LBM 008 showed the highest activity over a longer period of time ( $3^{\text {th }}$ to $15^{\text {th }}$ culture day). This result was lower compared with that reported by Falkoski et al. [27] for $P$. sanguineus grown on sugarcane bagasse as carbon source. These results agree with Diorio et al. [28] using different lignocellulosic substrates, where EGs and EXs showed lower activity using wood wastes.

Analyzing the bar graphs in Figure 1, it can be seen that BGLs activity curves for P. sanguineus LBM 014 and Irpex sp. LBM 034 displayed a negative skewed behavior both with the maximum at $12^{\text {th }}$ culture day (34 and $8 \mathrm{U} / \mathrm{L}$ respectively), whereas EGs showed a positive skewed behavior, with a maximum for $P$. sanguineus LBM 014 on the $3^{\text {rd }}$ culture day (562 $\mathrm{U} / \mathrm{L})$ and Irpex LBM 034 on the $9^{\text {th }}$ culture day $(541 \mathrm{U} / \mathrm{L})$. It must be pointed out that the enzyme activity for Irpex sp. LBM 034 growing on wood flour as substrate was higher than using wood chips as substrate $(1 \mathrm{U} / \mathrm{L})$ for 4 to 6 days [29]. CBHs from $P$. sanguineus LBM 014 reached the maximum value on the $15^{\text {th }}$ culture day $(16 \mathrm{U} / \mathrm{L})$. Regarding this strain, each enzyme displayed maximum activity at different times. CBHs from Irpex sp. LBM 034 exhibited two peaks, 33 and 26 U/L on the day 3 and 15, respectively.

Irpex sp. BAFC 1171 and Irpex sp. LBM 032 showed two peaks of EGs, for Irpex sp. BAFC 1171 on the $3^{\text {rd }}$ and $9^{\text {th }}$ days $\left(667\right.$ and $847 \mathrm{U} / \mathrm{L}$ ) and for Irpex sp. LBM 032 on the $6^{\text {th }}$ and $15^{\text {th }}$ days (821 and $\left.762 \mathrm{U} / \mathrm{L}\right)$. CBHs had similar behavior as EGs for Irpex sp. LBM 032 whereas Irpex sp. BAFC 1171 showed a bell-like behavior with the maximum value at $9^{\text {th }}$ day (42 U/L). Irpex sp. BAFC 1171 exhibited a positive skewed behavior for BGLs with a maximum at $9^{\text {th }}$ day, however Irpex sp. LBM 032 had an incremental pattern, rising slowly until the last day (10 U/L), when the three enzymes had similar and maximum activity.

For $P$. sanguineus BAFC 2126, EGs secretion pattern had a negative skewed behavior with a maximum at the $12^{\text {th }}$ day (291 U/L) and BGLs showed two peaks, at days 6 and 15 (15 and $17 \mathrm{U} / \mathrm{L}$, respectively). This strain had a normal shape behavior with a maximum for CBHs (129 U/L- day 9). Yoon et al. [30] found similar results for FPA (80 U/L on the $6^{\text {th }}$ culture day), and EGs activity on the $9^{\text {th }}$ culture day $(203 \mathrm{U} / \mathrm{L})$ for $P$. sanguineous grown in medium supplied with sugarcane bagasse, but lower BGLs activity $(17 \mathrm{U} / \mathrm{L})$ on the $15^{\text {th }}$ culture day. $P$. sanguineous BAFC 2126 showed higher CBHs activity (129 U/L) compared with L. elegans (76 U/L) and Irpex sp. LBM 032 presented in this and another work [27].

EGs from $L$. elegans had normal bell shape pattern throughout the time with a peak at $9^{\text {th }}$ culture day $(528 \mathrm{U} / \mathrm{L})$, whereas $\mathrm{CBHs}$ and BGLs increased gradually until rising the maximum at day 15 (10 U/L for BGLs).

Dynamic knowledge of enzyme is important for efficient biotechnological applications [6]. According to the present results, PWF and EWF proved to be suitable carbon source to produce hydrolytic enzymes. I. lacteus BAFC 1171 and $P$. sanguineus BAFC 2126 have potential for cellulase production when growing on wood flour as a carbon source, since both fungi not only present filter paper activity, but also produce EGs, BGLs and CBHs. $P$. sanguineus LBM 008 secreted high EXs activity over an extended period of time. This function is remarkable because some biotechnological application require mixtures of cellulases and hemicellulases for maximum benefits [31]. To accomplish an efficient saccharification process, high activities of EGs, BGLs and CBHs are necessary to degrade cellulose and high EXs activity to degrade hemicellulose, thus increasing yields to obtain bioetanol by fermenting 5 and 6 carbon sugars. Nevertheless, it is still necessary to explore other variables to improve these levels of cellulase and xylanase using wood flour as substrate.

\section{ACKNOWLEDGMENTS}

This study was supported by PICTO - UNaM 2011-0086, ANPCyT, Ministerio de Ciencia, Tecnología e Innovación Productiva, República Argentina. Authors wish to thank the financial support from Secretaría General de Ciencia y Tecnología de la Universidad Nacional de Misiones, through grants for innovation projects (16Q446).

MDR and MLB have fellowships from Consejo Nacional de Investigaciones Científicas y Técnicas (CONICET), Argentina.

\section{REFERENCES}

[1] Abril, D. and Abril, A. 2009. Ethanol from lignocellulosic biomass. Cien. Inv. Agr. 36 (2), 177-190.

[2] Galbe, M. and Zacchi,G. 2002. A review of the production of ethanol from softwood. Appl. Microbiol. Biotechnol. 59, 618-628.

[3] Lima, M. A., Gomez, L. D., Steele-King, C. G., Simister, R., Bernardinelli, O. D., Carvalho, M. A., Rezende, C. A., Labate, C. A., Azevedo, R. E., McQueen-Mason, J. S. and Polikarpov, I. 2014. Evaluating the composition and processing potential of novel sources of Brazilian biomass for sustainable biorenewables production. Biotech. Biofuels 7, 1-10.

[4] Zhang, Y-H. P., Himmel, M. E. and Mielenz, J. R. 2006. Outlook for cellulase improvement: Screening and selection strategies. Biotechnol. Adv. 24, 452-481. 
[5] Elisashvili, E., Kachlishvili, E. and Penninckx, M. 2008. Effect of growth substrate, method of fermentation, and nitrogen source on lignocellulose-degrading enzymes production by white-rot basidiomycetes. J. Ind. Microbiol. Biotechnol. 35, 1531-1538.

[6] Lynd, L. R., Weimer, P. J., van Zyl, W. H. and Pretorius, I. S. 2002. Microbial Cellulose Utilization: Fundamentals and Biotechnology. Microbiol. Mol. Biol. Rev. 66 (3), 506-577.

[7] Prasad, P., Tanuja, Bedi, S. 2014. Polyphasic Characterization of A Potential Novel Cellulolytic Bacterium Brevibacillus Brevis Strain St-2. Journal of Advances in Biotechnology 4(1), 319-326.

[8] Bano, S., Qaderb, S., Amanb, A., Syedc, M., Durrani, K. 2013. High production of cellulose degrading endo-1,4- $\beta$-Dglucanase using bagasse as a substrate from Bacillus subtilis KIBGE HAS. Carbohyd. Polym. 91, 300-304.

[9] Jaradat, Z., Dawagreh, A., Ababneh, Q. and Saadoun, I. 2008. Influence of Culture Conditions on Cellulase Production by Streptomyces Sp. (Strain J2). Jordan J. Biol. Sci. 1(4), 141-146.

[10] Lee, Y., Kim, H., Gao, W., Chung, C., Lee, J. 2012. Statistical Optimization for Production of Carboxymethylcellulase of Bacillus amyloliquefaciens DL-3 by a Recombinant Escherichia coli JM109/DL-3 from Rice Bran Using Response Surface Method. Biotechnol. Bioproc. 17, 227-235.

[11] Asha, B., Revathi, M., Yadav, A. and Sakthivel, N. 2012. Purification and Characterization of a Thermophilic Cellulase from a Novel Cellulolytic Strain, Paenibacillus barcinonensis. J. Microbiol. Biotechnol. 22(11), 1501-1509.

[12] Ezekiel, C. N., Odebode, A. C., Omenka, R. O. and Adesioye, F. A. 2010. Growth response and comparative cellulase induction in soil fungi grown on different cellulose media. Acta SATECH. 3(2), 52-59.

[13] Niranjane, A., Madhou, P. and Stevenson, T. 2007. The effect of carbohydrate carbon sources on the productionof cellulase by Phlebia gigantea. Enzyme Microb. Tech. 40, 1464-1468.

[14] Hao, X., Yul, X. and Yan, Z. 2006. Optimization of the Medium for the Production of Cellulase by the Mutant Trichoderma reesei WX-112 Using Response Surface Methodology. Food Technol. Biotechnol. 44(1), 89-94.

[15] Sathler, L. A., Contiero, J. and Cazetta, M. L. 2015. Yacon Flour and Corn Steep Liquor as Substrates for Inulinase and Biomass Production by Kluyveromyces marxianus NRRL Y-7571. Journal of Advances in Biotechnology 4(3), 414-423.

[16] NREL/TP-510-42621. 2008. Determination of Total Solids in Biomass and Total Dissolved Solids in Liquid Process Samples. National Renewable Energy Laboratory U.S. Department of Energy.

[17] NREL/TP-510-42619. 2008. Determination of Extractives in Biomass. National Renewable Energy Laboratory U.S. Department of Energy.

[18] NREL/TP-510-42618. 2011. Determination of Structural Carbohydrates and Lignin in Biomass. National Renewable Energy Laboratory U.S. Department of Energy.

[19] López-Miranda, J., Soto-Cruz, N., Rutiaga-Quiñones, O. M., Medrano-Roldán, H. and Arévalo-Niño, K. 2009. Optimización del proceso de obtención enzimática de azúcares fermentables a partir de aserrín de pino. Rev. Int. Contam. Ambient. 25, 95-102.

[20] Ghose, T. 1987. Measurement of cellulase activities. Pure Appl. Chem. 59, 257-268.

[21] Bailey, M. J. 1981. The effect of $\beta$-glucosidase on some assays for cellulolytic enzymes. Biotechnol. Lett. 3 (12), $695-$ 700.

[22] Wood, T. and Bhat, M. 1988. Methods for measuring cellulase activities. Methods Enzymol. 160, 87-112.

[23] Miller, G. L. 1959. Use of dinitrosalicylic acid reagent for determination of reducing sugars. Ana.I Biochem. 31,: 426428.

[24] Gómez, E. A., Ríos, L. A. and Peña, J. D. 2012. Madera, un Potencial Material Lignocelulósico para la Producción de Biocombustibles en Colombia. Información Tecnológica 23(6), 73-86.

[25] Galbe, M. and Zacchi, G. 2002. A review of the production of ethanol from softwood. Appl. Microbiol. Biotechnol. 59, 618-628.

[26] López-Miranda, J., Soto-Cruz, N., Rutiaga-Quiñones, O. M., Medrano-Roldán, H. and Arévalo-Niño, K. 2009. Optimización del proceso de obtención enzimática de azúcares fermentables a partir de aserrín de pino. Rev Int. Contam. Ambient. 25, 95-102.

[27] Falkoski, D., Monteze Guimarães,V., Nicolau de Almeida, M., Couto Alfenas, A., Colodette, J. and Tavares de Rezende, S. 2012. Characterization of Cellulolytic Extract from Pycnoporus sanguineus PF-2 and Its Application in Biomass Saccharification. Appl. Biochem. Biotechnol. 166, 1586-1603.

[28] Diorio, L., Forchiassin, F., Papinutti, V. and Sueldo, D. 2003. Actividad enzimática y degradación de diferentes tipos de residuos orgánicos por Saccobolus saccoboloides (Fungi, Ascomycotina). Rev. lberoam. Micol. 20,11-15. 
[29] Giorgio, E. M., Morales, A., Congost, G., Fonseca, M. I., Abate, C., Zapata, P. D. and Villalba, L. L. 2013. Evaluación en laboratorio de un sistema sumergido de producción de Endo-1,4- $\beta$-Glucanasa secretada por dos cepas de hongos de pudrición blanca. Rev. Cienc. Tecnol. 15(19), 18-23.

[30] Yoon, L. W., Ngoh, G. C. and Chua, A. S. M. 2013. Simultaneous production of cellulase and reducing sugar through modification of compositional and structural characteristic of sugarcane bagasse. Enzyme Microb. Tech. 53, $250-256$.

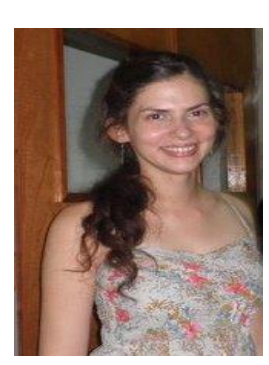

[31] Bhat, M. 2000. Cellulases and related enzymes in biotechnology. Biotechnol. Adv. 18, 355-383.

\section{Author' biography with Photo}

María Daniela Rodríguez is graduated in Chemical Engineer from Universidad Nacional de Misiones. She is student of PhD in Applied Science in Universidad Nacional de Misiones. Her current interests are on the topics of fermentation and enzymatic applications. 